\title{
ノッズル・ゼットの水平到達距離に関する研究 \\ STUDY ON THE COMPUTATION OF HORIZONTAL DISTANCE \\ OF JET ISSUED FROM NOZZLE
}

川上謙太 太郎*

By Kentaro Kawakami

\section{1.まえがき}

消火用のノッズルやダムのスキージャンプ式余水路の 末端から射出する高速度のゼット・射出水の径路や水平 到澾距離を考究することは土学的に意義がある。

かかる高速度射出水の運動の径路に対す万空気抵抗の 影響は，その運動の規模によって大いに左右されるもの と考えられる。一般的にはゼット水流はその射出口の構 造により水流の抎散状態が異なり，この抬散状態により 空気の抵抗の影響も相違してくるものと考えられてい る⿸尸

本文は空気の抵抗係数を考慮してフリーマンの消防用 ノッズルによる高速度射出水の運動の実験結 果を考察 し，空気の抵抗に関連する係数を決定する方法を示して いる。この空気抵抗に関連する係数 $k$ はゼットの流速 と射出口の断面形状によって決まる值であり，この係数 を使用することにより，ごく簡単にゼットの水平到達趾 離を算定することができる。かかる手法は多少の実測デ 一タのあるすべての空気抵抗をうけるゼット流の問題に 適用できると考えられる。

土木におけるゼット流の問題としてはダム余水吐の問 題があるが，これらについては現在空気の抵抗は影響し ないものと考えられ，その軌道は放物線軌道にしたがう ものと考えられている21。

しかし水流の規模・構造などによって, 空気の抵抗を 考慮すべきゼット流においては, その観測データを合理 的にまとめ, 簡単な計算式にまとめる方法として役立つ ものと洘えたので計算例とともに報告する。

* 正会員 工博 近畿大学教授 理工学部土木工学科

\section{2. 射出水の運動の式}

\section{（1）空気の抵抗を受ける運動の式}

物体が空中在運動する場合はかならず空気の抵抗を受 ける。これまでの実験によれば，速度が大きくなるとそ の抵抗は速度のおよそ 2 乗に比例する。以ま運動の方向 を水平と垂直方向に分け, 距離は前者を $x$, 後者を $y$ で 表わせば，速度はそれぞれ $d x / d t$ および $d y / d t$, 加速 度は $d^{2} x / d t^{2}$ および $d^{2} y / d t^{2}$ で表わされる。よって抵 抗係数を $K$ と寸れば 2 つの方向の抵抗力は $K(d x / d t)^{2}$ および $K(d y / d t)^{2}$ で表わされる。ここに $K$ は物体の 大小，形状に関係する実験值である。この抵抗は物体の 運動について速度を減らす力になるから負の力である。 このことから射出水が斜め上に飛び出した場合, 水平に 働く力は $-K(d x / d t)^{2}$, 垂直方向には運動の方向と反 対に重力と $-K(d y / d t)^{2}$ が同時に働くので, 水平およ び垂直方向の運動は次式で表わされる。

$$
\begin{aligned}
& M \frac{d^{2} x}{d t^{2}}=-K\left(\frac{d x}{d t}\right)^{2} \\
& M \frac{d^{2} y}{d t^{2}}=-M_{g}-K\left(\frac{d y}{d t}\right)^{2}
\end{aligned}
$$

いま係数 $k$ を用いて $K / M=g k^{2}$ と表わせば

$$
\begin{aligned}
& \frac{d^{2} x}{d t^{2}}=-g k^{2}\left(\frac{d x}{d t}\right)^{2} \ldots \\
& \frac{d^{2} y}{d t^{2}}=-g-g k^{2}\left(\frac{d y}{d t}\right)^{2}
\end{aligned}
$$

を得る。ここで $k$ は空気の抵抗に関係する係数である。

（2）水平および垂直方向の運動の式（図一1 参照）

まず水平方向の運動の式は式 (1) を積分して得られ る。

$$
\frac{d}{d t}\left(\frac{d x}{d t}\right)=-g k^{2}\left(\frac{d x}{d t}\right)^{2}
$$




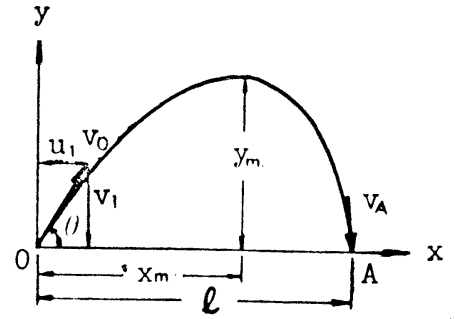

図-1 射出水の径路

水平速度 $d x / d t$ を $u$ とすれば, $d u / d t=-g k^{2} u^{2}$ よ り $d u / u^{2}=-g k^{2} \cdot d t$, これを積分すれば

$$
-\frac{1}{u}=-g k^{2} t+C_{1}
$$

水平初速度を $u_{1}$ とすれば $t=0$ に掠いて $u=u_{1}$ であ るから $C_{1}=-1 / u_{1}$ となり

$$
u=\frac{1}{\frac{1}{u_{1}}+g k^{2} t}
$$

をうる。さらに $u=d x / d t$ より

$$
\begin{gathered}
x=\frac{1}{g k^{2}} \ln \left(\frac{1}{u_{1}}+g k^{2} t\right)+C_{2} \\
t=0 \text { のをき } x=0 \text { であるから } \\
x=\frac{1}{g k^{2}} \ln \frac{\frac{1}{u_{1}}+g k^{2} t}{\frac{1}{u_{1}}}
\end{gathered}
$$

あるいは

$$
x=\frac{1}{g k^{2}} \ln \left(1+g k^{2} u_{1} t\right)
$$

これは水平方向における距離と時間の関係を表わす。 次に垂直方向の運動については式 (2) から

$$
\frac{d v}{d t}=-g\left(1+k^{2} v^{2}\right)
$$

これを積分して

$$
t=-\frac{1}{g k} \tan ^{-1}(k v)+C_{3}
$$

積分定数 $C_{3}$ は $t=0$ のとき $v=v_{1}$ より

$$
C_{3}=\frac{1}{g k} \tan ^{-1}\left(k v_{1}\right)
$$

\section{とえられる。}

ゆえに

$$
t=\frac{1}{g k}\left\{\tan ^{-1}\left(k v_{1}\right)-\tan ^{-1}(k v)\right\}
$$

より

$$
v=\frac{1}{k} \int \tan \left\{\tan ^{-1}\left(k v_{1}\right)-g k t\right\}
$$

ここに $\tan ^{-1}\left(k v_{1}\right) \equiv \alpha$ とすれば， $k$ と $v_{1}$ が与えられ るとき $\alpha$ は定の角度を表わす。よって式 (5) より

$$
y=\frac{1}{k} \int \tan (\alpha-g k t) \cdot d t+C_{4}
$$

$\alpha-g k t=z$ とおけば， $\alpha$ は定数であるから $d t=-d z / g k$ より

$$
\int \tan (\alpha-g k t) d t=\frac{1}{g k} \ln \cos (\alpha-g k t)
$$

よってyの式は

$$
y=\frac{1}{g k^{2}} \ln \cos (\alpha-g k t)+C_{4}
$$

$t=0$ のとき $y=0$ であるから $C_{4}=-\frac{1}{g k^{2}} \ln \cos \alpha$

ゆえに

$$
y=\frac{1}{g k^{2}} \ln \frac{\cos (\alpha-g k t)}{\cos \alpha}
$$

式（6）は垂直方向の距離と時間との関係を表わす。

\section{（3）射出水の径路の式}

射出水の水平距離 $x$ とその高度 $y$ の関係を表わす射出 水の径路の式は, 式 (4) と（6）功時間 $t$ を消去し て得られる。まず式 (4)

$$
x=\frac{1}{g k^{2}} \ln \left(1+g k^{2} u_{1} t\right) \text { より } 1+g k^{2} u_{1} t=e^{g k^{2} x}
$$

ゆえに

$$
t=\frac{1}{g k^{2} u_{1}}\left(e^{g k^{2} x}-1\right) \equiv \beta
$$

となる。

次に式 (6) に掠いて $\cos (\alpha-g k t)$ を展開して整理す れば,

$$
\begin{aligned}
y & =\frac{1}{g k^{2}} \ln \frac{\cos (\alpha-g k t)}{\cos \alpha} \\
& =\frac{1}{g k^{2}} \ln (\cos g k t+\tan \alpha \cdot \sin g k t)
\end{aligned}
$$

この式の $t$ を $\beta$ で置き換えて

$$
y=\frac{1}{g k^{2}} \ln (\cos g k \beta+\tan \alpha \cdot \sin g k \beta)
$$

ここに, $y$ : 原点より $x$ の水平距離 $(\mathrm{m})$ にある射出水 の高度 $(\mathrm{m})$

$k:$ 空気の抵抗に関係ある係数

$$
\begin{aligned}
& k=0.00057 v_{0}+\frac{0.000021}{m^{1.35}} \text { (式 (19) 参照) } \\
& m=\frac{A}{p}
\end{aligned}
$$

$A:$ 射出水始点の断面積 $\left(\mathrm{m}^{2}\right)$

$p:$ 空気に接する $A$ の周長 $(\mathrm{m})$

$v_{0}:$ 射出水の始点に㧍ける速度 $(\mathrm{m} / \mathrm{sec})$

$$
\begin{aligned}
& \beta=\frac{e^{g k^{2} x}-1}{g k^{2} u_{1}}(\mathrm{sec}) \\
& \alpha=\tan ^{-1}\left(k v_{1}\right)(\mathrm{rad})
\end{aligned}
$$

$u_{1}: v_{0}$ の水平分速度 $=v_{0} \cos \theta(\mathrm{m} / \mathrm{sec})$

$v_{1}: v_{0}$ の垂直分速度 $=v_{0} \sin \theta(\mathrm{m} / \mathrm{sec})$

$\theta$ : 原点において射出水が水平軸となす角度

$g:$ 重力の加速度 $=9.8\left(\mathrm{~m} / \mathrm{sec}^{2}\right)$

$\ln$ : 自然対数 $\left(=2.3 \log _{10}\right)$ 


\section{（4）射出水の達する水平距離}

水平到達距離は式 (6) において $y=0$ と才く。

$$
\ln \frac{\cos (\alpha-g k t)}{\cos \alpha}=0 \text { より } \alpha-g k t= \pm \alpha
$$

ゆえに $t=0$ および $t=2 \alpha / g k$ をうる。 $t=0$ は径路の始 点で題意にそわない。ゆえに $t=2 \alpha / g k$ の時間におい て, 射出水は始点と同じ高さの位置に達する。

よって求める水平距離 $l$ はこれを式 (4) に代入し

$$
l=\frac{1}{g} \overline{k^{2}} \ln \left(1+2 k \alpha u_{1}\right)
$$

こえられる。

\section{（5） 射出水の最大高度 $\boldsymbol{y}_{m}$ とその水平距離 $\boldsymbol{x}_{m}$}

$y_{m}$ を求めるには式 (6) を $t$ について微分して 0 と おけばよい。 $\tan (\alpha-g k t)=0$ より $\alpha-g k t=0$, すなわち $t=\alpha / g k$, この值を式（6）に代入して $y_{m}$ をえる。

$$
y_{m}=\frac{1}{g k^{2}} \ln \sec \alpha
$$

$\Xi こ に \alpha=\tan ^{-1}\left(k v_{1}\right)$ ( $\left.\mathrm{rad}\right)$

次に $x_{m}$ の式は次の上らになる。

$y_{m}$ は $t=\alpha / g k$ におこるので, $一$ の值在式 (4) に代 人すれば

$$
r_{m}=\frac{1}{g k^{2}} \ln \left(1+g k^{2} u_{1} \frac{\alpha}{g k}\right)
$$

すなおた

$$
x_{m}=\frac{1}{g k^{2}} \ln \left(1+k u_{1} \alpha\right)
$$

より計算される。

\section{（6）水平距離 $\boldsymbol{l}$ を最大にする射出角 $\boldsymbol{\theta}$}

式（8）に $\alpha=\tan ^{-1}\left(k v_{1}\right), v_{1}=v_{0} \sin \theta, u_{1}=v_{0} \cos \theta$ を代入し

$$
l=\frac{1}{g k^{2}} \ln \left\{1+2 k \cdot \tan ^{-1}\left(k v_{0} \sin \theta\right) \cdot v_{0} \cos \theta\right\}
$$

$\alpha, v_{0}$ を定数とみなし， $d l / d \theta=0$ より式 (11) をえる。

$$
\frac{k v_{0}}{1+k^{2} v_{0}^{2} \sin ^{2} \theta}=\tan \theta \cdot \sec \theta \cdot \tan ^{-1}\left(k v_{0} \sin \theta\right)
$$

この式を満足する $\theta$ が求める角度となる。 $\theta$ は空気の 抵抗がない場合は $45^{\circ}$ であるが, 抵抗がある場合は $k$ および $v_{0}$ によってかわる。たとえば $v_{0}=36.4 \mathrm{~m} / \mathrm{sec}$, $k=0.02,0.03,0.04$ に対し $\theta=42^{\circ}, 41^{\circ}, 39^{\circ}$ のようにか わる。

\section{（7）射出水の末端の速度}

図一1のA点における射出水の速度 $v_{A}$ を求める。そ のためにはA点における水平分速度 $u_{2}$ および垂直分速 度 $v_{2}$ を合成すればよい。水平分速度は式（3）で表わ
されるから，この式に射出水がA点に達するまでの時間 $t=2 \alpha / g k$ を代人して

$$
u_{2}=\frac{1}{\frac{1}{u_{1}}+g k^{2} \frac{2 \alpha}{g k}}=\frac{1}{\frac{1}{u_{1}}+2 k \alpha}
$$

垂直分速度は式 (5) に $t=2 \alpha / g k$ を代入して

$$
v_{2}=\frac{1}{k} \tan \left(\alpha-g k \frac{2 \alpha}{g k}\right)=-\frac{1}{k} \tan \alpha
$$

ゆえに

$$
v_{A}=\sqrt{u_{2}^{2}+v_{2}^{2}}
$$

式（14）より射出水が $x$ 軸と交わるA点における速度 が計算される。しかし射出水の末端近くでは断面が若干 拡散するので, 実際の速度はこれより小さくなるであろ 5 。

\section{3. 係数 $k$ の算定式}

\section{（1） $k$ の考察と式形の選び方}

$k$ の性格は 2. (1) において $k^{2}=K / M g$ と定義して空 気の抵抗係数と関連をもたせた。その值は実験の結果か ら定まるものであるが，直接に測定することはむずかし いしかし射出水の水平到達距離の実験值があれば, こ れを $し$ 式 (8) に適用して間接に $k$ を算定することが "できる。本文では次のよ その概要は次のとおりである。

1）フリーマンの実験值 ${ }^{3}$ を式 (8) に代人して $k$ を 算定し,

2)この $k$ とノッズル出口の水の速度 $v^{4}$ との関係 を図一2 に示して $k=a v+b$ の直線式をつくった。

3）図一2によれば, 直線式の $a$ の值は 3 種のノッズ ルに共通した同じ值であるが，第 2 項 $b$ の值はノッズル の口径によって違っている。そこで直線式第 1 項は速度 による影響項, 第 2 項は射出水の断面の寸法, 形状によ ってかわる項と考え， $k$ の式を式 (15) のように組みか えた。

$$
k=k_{v}+k_{m}
$$

ここに， $k_{v}: v$ に相応する $k$,

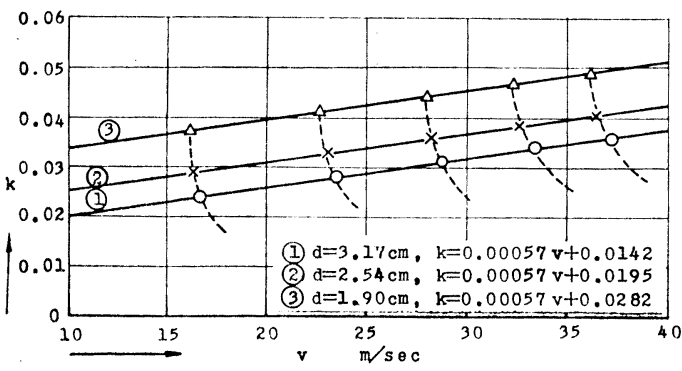

図一2 フリーマンの実験值 $l_{F}$ より算定した $k$ の図 


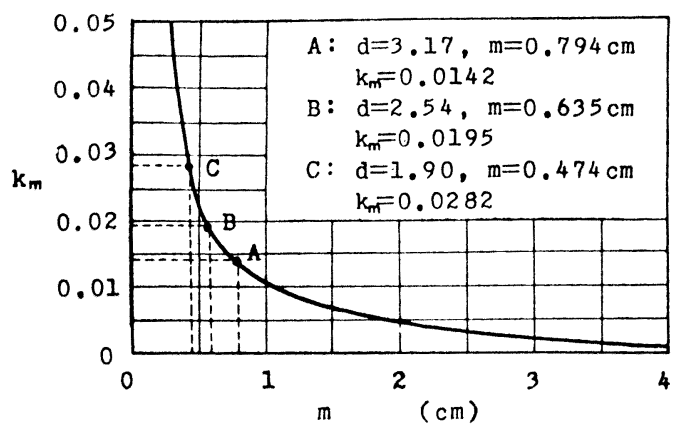

図-3 $\boldsymbol{k}_{m}$ と $\boldsymbol{m}$ の関係 (図一2 の式の定数より)

$k_{m}: m$ に相応する $k$,

$m=A / p, A:$ 射出水始点の断面積

$p:$ 断面の空気に接する周長

4） $k m$ に対する $m$ の影響は 図一3 のように表わさ れる。

そこで

$$
k_{m}=\frac{r}{m^{n}}
$$

ここに $r, n:$ 定数,

の式を採用して, $r$ と $n$ を図一3の実験資料から算定し た。

5） らえの $k_{v}$ と $k_{m}$ をあわせて式 (19) の $k$ の式 を決定した。この $k$ の精度は 表一1 に示した。

\section{（2）フリーマンの実験值 $\boldsymbol{l}_{F}$ を引用した $\boldsymbol{k}$ の式}

フリーマン（J.R. Freeman, アメリカ) は消火用) ッズルの放水試験において $l$ の最大值 ${ }^{3)}$ を測定した。こ の値を引用し, 放水試験の資料であるノッズル口径 $d$, 水圧, 速度 $v_{0}, l$ の実測值 $l_{F}$ は 表一2 に示した。こ の $l_{F}$ を用いて式 (8) により計算した $k_{F}$ の值は表一 1 に示したが, ノッズル出口の水の速度 $v_{0}$ と $k_{F}$ の関 係を図示して 図一2 がえられる。これらはノッズルの 口径ごとに 1 つの直線となる。直線を $k=a v+b$ として 式をつくったが，vの係数 $a$ をわずか修正して共通の值 にして, 次の関係式をえた。

$$
\text { ノッズルロ径 } d \quad k \text { の式 }
$$

$3.17 \mathrm{~cm}(11 / 4$ in) $\quad k=0.00057 v+0.0142 \cdots(17 \cdot \mathrm{a})$

$2.54 \mathrm{~cm}(1 \mathrm{in}) \quad k=0.00057 v+0.0195 \cdots(17 \cdot \mathrm{b})$

$1.90 \mathrm{~cm}(3 / 4 \mathrm{in}) \quad k=0.00057 v+0.0282 \cdots(17 \cdot \mathrm{c})$

これら 3 つの式は口径の違った放水について $k$ を $v$ の関数として表わしているが，この中に $m$ の影響も含 んでいるものと考え, 式 (17) の第 1 項は $v$ の影響す る項, 第 2 項は $m$ の影響する項と 2 つ分けて考える ものとした。すなわち $k$ の式として式 (15) を考える。 なお式 (17) の適用の範囲は $v=0$ まで延長することは 適当でない。少なくとも $v=10 \mathrm{~m} / \mathrm{sec}$ 程 度が限度であ
ろら。

\section{(3) $k_{m}=\gamma / m^{n}$ の定数の決定}

式 (15) のごとく $k$ を $k_{v}$ と $k_{m}$ に分けた結果, $k_{m}$ は式 (17) の第 2 項に対応する。この式 (17) の右辺第 2 項とノッズルの $m$ の関係を示すと 図一3 のようにな る。すなわち $k_{m}$ に対する $m$ の影響はノッズルの口径 が小さいほど大きく， 口径が大きいほど小さくなる傾向 を示している。このような $m$ と $k_{m}$ の関係を, $m=0$, の 場合 $k_{m}$ 值が $\infty, 0$ になるべきこともあわせ考慮 して，式（16）の形を仮定した。図一3 の資料からこの 式の $r$ とを最小自乗法の方法より算定して次の式をえ た。

$$
k_{m}=\frac{0.000021}{m^{1.35}}
$$

この式は式 (17) の右辺第 2 項を $m$ の関数として式 化したものである。

\section{（4） $k$ の式の決定}

式（17）および（18）を一括して式（15）に適用して 式（19）をえた。

$$
k=0.00057 v+\frac{0.000021}{m^{1.35}}
$$

ただし, $v: \mathrm{m} / \mathrm{sec}, v>10 \mathrm{~m} / \mathrm{sec}$

これが射出水の始点の速度と断面, 形状を考慮した $k$ の式になる。

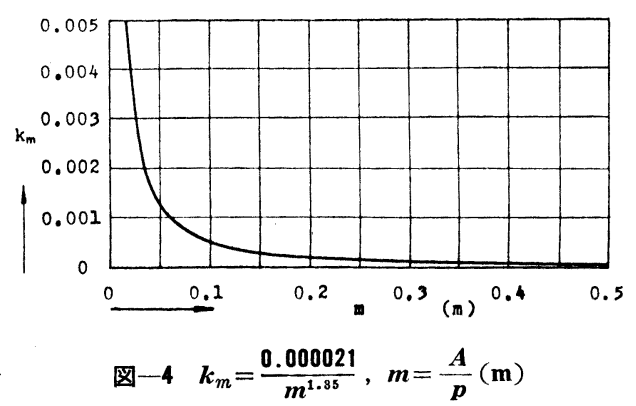

なお式 (18) により $k_{m}$ を計算する際には, 図一4を利 用すればよい。

\section{（5） $k$ 式の精度（表一1 参照）}

さきにフリーマンの $l_{F}$ から計算した $k$ を $k_{F}$ とし， 式 (19) から計算した $k$ を $k_{c}$ として, 次の計算によ ってその精度を調べた。

$$
\sigma_{r}=\left\{\sum_{1}^{N}[V V] / N\right\}^{1 / 2}, V=\frac{k_{F}-k_{c}}{k_{F}}
$$

ノッズル口径 $3.17,2.54,1.90 \mathrm{~cm}$ に対し $\sigma_{r}$ はそれ ぞれ 3.3，1.8，1.7（\%) になり, 式 (19) の精度はか なり高いものと考えられる。 
表一1 $k_{c}$ の $k_{F}$ に対する精度

\begin{tabular}{|c|c|c|c|c|c|c|}
\hline $\begin{array}{l}\text { ノッズル } \\
\text { 口径 }\end{array}$ & $\underset{\mathrm{kg} / \mathrm{cm}^{2}}{\text { 压 }}$ & $k_{F}$ & $k_{c}$ & $k_{F}-k_{c}$ & $V$ & {$[\underset{\%}{V V}]$} \\
\hline \multirow{6}{*}{$3.17 \mathrm{~cm}$} & 1.4 & 0.0232 & 0.0240 & -0.0008 & -0.0354 & 12.5 \\
\hline & 2.8 & 0.0262 & 0.0277 & -0.0015 & -0.0572 & 32.7 \\
\hline & 4.2 & 0.0312 & 0.0308 & +0.0004 & +0.0128 & 1.6 \\
\hline & 5.6 & 0.0339 & 0.0333 & +0.0006 & +0.0147 & 2.2 \\
\hline & 7.0 & 0.0355 & 0.0364 & -0.0009 & -0.0253 & 6.4 \\
\hline & \multicolumn{5}{|c|}{$N=5, \sigma_{r}=\{55.4 / 5\}^{1 / 2}=3.3 \%$} & 55.4 \\
\hline \multirow{6}{*}{$2.54 \mathrm{~cm}$} & 1.4 & 0.0290 & 0.0287 & +0.0003 & +0.0103 & 1.1 \\
\hline & 2.8 & 0.0315 & 0.0325 & -0.0010 & -0.0317 & 10.0 \\
\hline & 4.2 & 0.0356 & 0.0355 & +0.0001 & +0.0028 & 0.8 \\
\hline & 5.6 & 0.0374 & 0.0380 & -0.0006 & -0.0160 & 2.6 \\
\hline & 7.0 & 0.0405 & 0.0401 & +0.0004 & +0.0099 & 1.0 \\
\hline & \multicolumn{5}{|c|}{$N=5, \sigma_{r}=\{15.5 / 5\}^{1 / 2}=1.8 \%$} & 15.5 \\
\hline \multirow{6}{*}{$1.90 \mathrm{~cm}$} & (1.4) & 0.0350 & 0.0379 & -0.0029 & -0.0828 & $(68.5)$ \\
\hline & 2.8 & 0.0422 & 0.0417 & +0.0005 & +0.0118 & 1.3 \\
\hline & 4.2 & 0.0459 & 0.0447 & +0.0012 & +0.0026 & 6.8 \\
\hline & 5.6 & 0.0478 & 0.0471 & +0.0007 & +0.0146 & 2.1 \\
\hline & 7.0 & 0.0488 & 0.0493 & -0.0005 & -0.0102 & 1.0 \\
\hline & \multicolumn{5}{|c|}{$N=4, \sigma_{r}=\{11.2 / 4\}^{1 / 2}=1.7 \%$} & 11.2 \\
\hline
\end{tabular}

表一2 $\boldsymbol{l}_{F}$ と $\boldsymbol{l}_{c}$ の比較

\begin{tabular}{|c|c|c|c|c|c|c|}
\hline 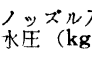 & & 1.4 & 2.8 & 4.2 & 5.6 & 7.0 \\
\hline $\begin{array}{l}\text { 口 径 } \\
3.17 \mathrm{~cm}\end{array}$ & $\begin{array}{c}v_{0} \\
k \\
l_{c} \\
l_{F}\end{array}$ & $\begin{array}{l}16.6 \\
0.0240 \\
25.1 \\
25.3\end{array}$ & $\begin{array}{l}23.4 \\
0.0277 \\
44.0 \\
45.1\end{array}$ & $\begin{array}{l}28.7 \\
0.0308 \\
57.1 \\
56.6\end{array}$ & $\begin{array}{l}33.2 \\
0.0333 \\
66.0 \\
64.9\end{array}$ & $\begin{array}{l}37.1 \\
0.0355 \\
71.6 \\
71.9\end{array}$ \\
\hline $\begin{array}{l}\text { 口 径 } \\
2.54 \mathrm{~cm}\end{array}$ & $\begin{array}{l}v_{0} \\
k \\
l_{c} \\
l_{F}\end{array}$ & $\begin{array}{l}16.3 \\
0.0287 \\
23.5 \\
23.5\end{array}$ & $\begin{array}{l}23.0 \\
0.0325 \\
40.1 \\
40.5\end{array}$ & $\begin{array}{l}28.2 \\
0.0355 \\
51.0 \\
50.9\end{array}$ & $\begin{array}{l}32.6 \\
0.0380 \\
57.9 \\
57.6\end{array}$ & $\begin{array}{l}36.4 \\
0.0401 \\
62.6 \\
62.5\end{array}$ \\
\hline $\begin{array}{l}\text { 口径 } \\
1.90 \mathrm{~cm}\end{array}$ & $\begin{array}{c}v_{0} \\
k \\
l_{c} \\
l_{F}\end{array}$ & $\begin{array}{l}16.1 \\
0.0379 \\
21.3 \\
21.9\end{array}$ & $\begin{array}{l}22.8 \\
0.0417 \\
34.4 \\
34.1\end{array}$ & $\begin{array}{l}28.0 \\
0.0447 \\
41.4 \\
41.5\end{array}$ & $\begin{array}{l}32.3 \\
0.0471 \\
47.4 \\
46.6\end{array}$ & $\begin{array}{l}36.1 \\
0.0493 \\
50.3 \\
50.9\end{array}$ \\
\hline
\end{tabular}

注 $: v_{0}, l_{F}$ は Freeman の実験值を引用し， $k, l_{c}$ は上の実験值を基に して著者が本文において算定した值とする。

（6）実験值 $\boldsymbol{l}_{F}$ と計算值 $\boldsymbol{l}_{c}$ の 比較（表一 2 , 表一-3 参照)

本文の算式

$$
\begin{aligned}
& l=\frac{2.30}{g k^{2}} \log \left(1+2 k \alpha u_{1}\right) \\
& k=0.00057 v+\frac{0.000021}{m^{1.35}}
\end{aligned}
$$

\section{4. 射出水の径路計算の例解}

\section{（1）放水ゼットの例}

\section{資料 フリーマンの放水試験}

ノッズルロ径 $d=3.17 \mathrm{~cm}$, 水圧: $=7 \mathrm{~kg} / \mathrm{cm}^{2}$

$v_{0}=37.1 \mathrm{~m} / \mathrm{sec}, l_{F}=71.9 \mathrm{~m}, m=\frac{d}{4}=0.00794 \mathrm{~m}$, $\theta=40^{\circ}$

\begin{tabular}{|c|c|c|c|c|c|c|}
\hline くッズル & $\underset{\mathrm{kg} / \mathrm{cm}^{2}}{\text { 水 }}$ & $l_{F}$ & $l_{c}$ & $l_{F}-l_{c}$ & $V$ & {$\left[\begin{array}{l}V V] \\
\%\end{array}\right.$} \\
\hline \multirow{6}{*}{$3.17 \mathrm{~cm}$} & 1.4 & 25.3 & 24.9 & +0.4 & +0.0158 & 2.49 \\
\hline & 2.8 & 45.1 & 44.0 & +1.1 & +0.0244 & 5.95 \\
\hline & 4.2 & 56.6 & 57.1 & -0.5 & -0.0088 & 0.77 \\
\hline & 5.6 & 64.9 & 66.0 & -1.1 & -0.0169 & 0.28 \\
\hline & 7.0 & 71.0 & 71.6 & +0.3 & +0.0041 & 0.17 \\
\hline & \multicolumn{5}{|c|}{$N=5, \sigma_{r}=\{9.66 / 5\}^{1 / 2}=1.39 \%$} & 9.66 \\
\hline \multirow{6}{*}{$2.54 \mathrm{~cm}$} & 1.4 & 23.5 & 23.5 & 0 & 0 & 0 \\
\hline & 2.8 & 40.5 & 40.1 & +0.4 & +0.0010 & 0.01 \\
\hline & 4.2 & 50.9 & 51.0 & -0.1 & -0.0020 & 0.04 \\
\hline & 5.6 & 57.6 & 57.9 & -0.3 & -0.0052 & 0.27 \\
\hline & 7.0 & 62.5 & 62.6 & -0.1 & -0.0016 & 0.02 \\
\hline & \multicolumn{5}{|c|}{$N=5, \sigma_{r}=\{0.34 / 5\}^{1 / 2}=0.26 \%$} & 0.34 \\
\hline \multirow{6}{*}{$1.90 \mathrm{~cm}$} & 1.4 & 21.9 & 21.3 & +0.6 & +0.0274 & 7.50 \\
\hline & 2.8 & 34.1 & 34.4 & -0.3 & -0.0088 & 0.77 \\
\hline & 4.2 & 41.5 & 41.4 & +0.1 & +0.0024 & 0.06 \\
\hline & 5.6 & 46.6 & 47.4 & -0.8 & -0.0169 & 2.86 \\
\hline & 7.0 & 50.9 & 50.3 & +0.6 & +0.0118 & 1.39 \\
\hline & \multicolumn{5}{|c|}{$N=5, \sigma_{r}=\{12.58 / 5\}^{1 / 2}=1.59 \%$} & 12.58 \\
\hline
\end{tabular}

表-3 $l_{c}$ の $l_{F}$ に対する精度

1) 空気の抵抗を考慮した場合

$\cos \theta=0.766, \sin \theta=0.643, \tan \theta=0.839$,

$u_{1}=r_{0} \cos \theta=28.42 \mathrm{~m} / \mathrm{sec}, v_{1}=v_{0} \sin \theta=23.85 \mathrm{~m} / \mathrm{sec}$, $\alpha=\tan ^{-1} k v_{1}=\tan ^{-1} 0.8443=40^{\circ} 10.5^{\prime}, \sec \alpha=1.3089$, $k=0.00057 \times 37.1+\frac{0.000021}{0.00794^{1.35}}=0.0355$, を用い

$$
\begin{aligned}
& l=\frac{2.30}{g k^{2}} \log \left(1+2 k \alpha u_{1}\right)=71.6 \mathrm{~m}, \\
& y_{m}=\frac{2.30}{g k^{2}} \log \sec \alpha=21.9 \mathrm{~m}, \\
& x_{m}=\frac{2.30}{g k^{2}} \log \left(1+k \alpha u_{1}\right)=43.4 \mathrm{~m}
\end{aligned}
$$

\begin{tabular}{|c|c|c|c|c|c|c|c|}
\hline \multicolumn{4}{|c|}{ 空気の抵抗を考虑した場合 } & \multicolumn{4}{|c|}{ 空気の抵抗を考䳸しない場合 } \\
\hline$x(\mathrm{~m})$ & $y(\mathrm{~m})$ & 位 & 置 & $x(\mathrm{~m})$ & $y(\mathrm{~m})$ & 位 & 置 \\
\hline 0 & 0 & \multirow[t]{5}{*}{ 始 } & \multirow[t]{5}{*}{ 点 } & 0 & 0 & \multirow[t]{7}{*}{ 始 } & 点 \\
\hline 10 & 7.78 & & & 10 & 7.78 & & \\
\hline 20 & 14.35 & & & 20 & 14.35 & & \\
\hline 30 & 19.15 & & & 30 & 19.71 & & \\
\hline 40 & 21.69 & & & 40 & 23.86 & & \\
\hline 43.4 & 21.89 & \multirow[t]{6}{*}{ 最高 } & 点 & 50 & 26.79 & & \\
\hline 50 & 21.05 & & & 60 & 28.51 & & \\
\hline 55 & 19.12 & & & 69.2 & 29.03 & 最 高 & 点 \\
\hline 60 & 15.76 & & & 70 & 29.01 & & \\
\hline 65 & 10.59 & & & 80 & 28.31 & & \\
\hline 70 & 3.01 & & & 90 & 26.39 & & \\
\hline \multirow[t]{5}{*}{71.6} & \multirow[t]{5}{*}{0} & \multirow[t]{5}{*}{ 終 } & \multirow[t]{5}{*}{ 点 } & 100 & 23.26 & & \\
\hline & & & & 110 & 18.52 & & \\
\hline & & & & 120 & 13.36 & & \\
\hline & & & & 130 & 6.59 & & \\
\hline & & & & 138.4 & 0 & 終 & 点 \\
\hline
\end{tabular}

射出水の径路は

$$
y=\frac{2.30}{g k^{2}} \log (\cos g k \beta+\tan \alpha \cdot \sin g k \beta)
$$

表一4 放水ぜットの径路の計算例 


$$
\beta=\frac{e^{g k^{2} x}-1}{g k^{2} u_{1}}=\frac{e^{0.11228 x}-1}{0.349}
$$

より凉算して表 4 に亦した。

2) 空気の抵抗を考慮しない壦合

$$
\begin{aligned}
& y=x\left\{\tan \theta-\frac{g}{2} \frac{x}{v_{0}{ }^{2} \cos ^{2} \theta}, l=\frac{v_{0}{ }^{2}}{g} \sin 2 \theta,\right. \\
& y_{m}=\frac{l}{4} \tan \theta, x_{m}=\frac{l}{2},
\end{aligned}
$$

より計算して 表一4 に示した。

3）放水ゼットの径路の図示

表-4 の結果を 図一5 に示し, 空気の抵抗を考慮し た場合と考慮しない場合の径路を比較した。

以上放水ゼットの初速度 $v_{0}$ が $37.1 \mathrm{~m}$ という比較的

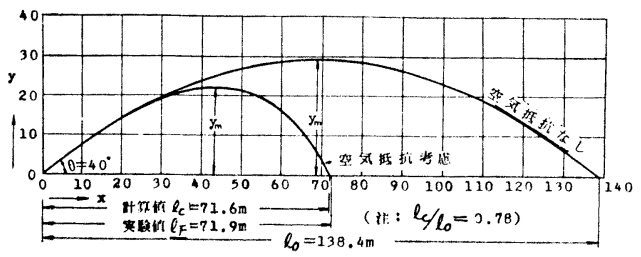

图 5 放水ゼットの径路の比較図 消火用ノッズル口径 $3.17 \mathrm{~cm}$ $v_{0}=37.1 \mathrm{~m} / \mathrm{sec}, k=0.0355$

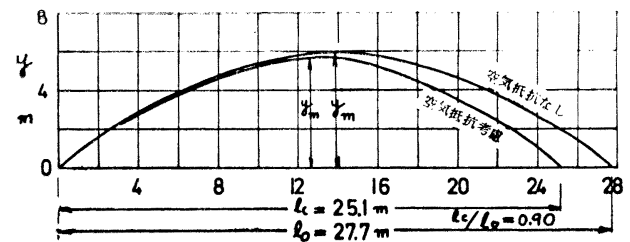

図一6 $\boldsymbol{l}_{c} / \boldsymbol{l}_{0}($ 表一5) の図法

表一5 射出水の初速度 $v_{0}$ と $\boldsymbol{l}_{c} / \boldsymbol{l}_{0}$

\begin{tabular}{c|l|c|c|c|c|c|c}
\hline $\begin{array}{c}\text { 水 压 } \\
\left(\mathrm{kg} / \mathrm{cm}^{2}\right)\end{array}$ & 0.4 & 0.7 & 1.4 & 2.8 & 4.2 & 5.6 & 7.0 \\
\hline$v_{0}(\mathrm{~m} / \mathrm{sec})$ & 8.6 & 11.4 & 16.6 & 23.4 & 28.7 & 33.2 & 37.1 \\
$k$ & 0.0187 & 0.0210 & 0.0240 & 0.0277 & 0.0308 & 0.0333 & 0.0355 \\
$l_{c}(\mathrm{~m})$ & 7.3 & 12.6 & 25.1 & 44.0 & 57.1 & 66.0 & 71.6 \\
$l_{0}(\mathrm{~m})$ & 7.4 & 13.1 & 27.7 & 55.0 & 82.8 & 110.8 & 138.3 \\
$l_{c} / l_{0}$ & 0.99 & 0.96 & 0.90 & 0.80 & 0.69 & 0.60 & 0.52 \\
\hline
\end{tabular}

注 $: l_{c}$ : 空気抵抗を考慮しな水平到達距離 $(\mathrm{m})$

$l_{0}$ : 空気抵抗を考慮しない水平到達距離 $(\mathrm{m})$ ノッズルロ径 $=3.17 \mathrm{~cm}$

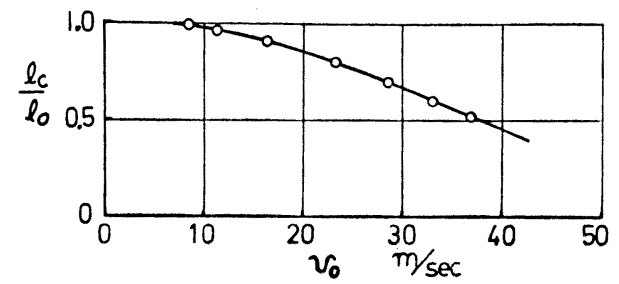

図-7 放水ゼットの径路の比較図

消火用ノッズルロ径 $3.17 \mathrm{~cm}$ $v_{0}=16.6 \mathrm{~m} / \mathrm{sec}, k=0.0240$
大きな場合についくの計算を例示したが，间じロ径で初

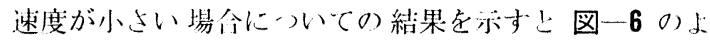
うになる。図一5上刘比してわかるようにひ。が大きい 是合には空気抵抗は大きいが， 抵抗はさほど影響しなくなる。

初速度 $v_{0}$ の変化により空気の抵抗の有無による水平 到達距離の比 $l_{c} / l_{0}$ がどのようにかわるかを示すと表一 5 および 図一7 のとおりである。

$v_{0}$ が大なる 場合空気抵抗の影響は大きいが， $v_{0}$ が小 なる場合空気抵抗の影響も小さくなることを示してお り, $v_{0}=8.5 \mathrm{~m} / \mathrm{sec}$ の時 $l_{c} / l_{0}=1$ で, この時放水軌道は 放物線となる。

\section{（2）大型射出水の例}

本文における空気の抵抗を考慮する係数 $k$ を求めた 式 (19) 中の数值は消防用ホースの放水試験の結果より 求めたものである。これをスキージャンプ式余水吐のご とき大型射出水の例にそのまま適用することには多少の 問題はあろう。しかしスキージャンプ余水吐の奏測例で

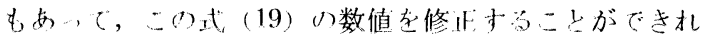
ば，ちらん適用は可能上なる。

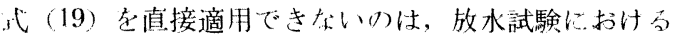
ぜットの拨散と余水时に抢ける拨散とが多少とも異な り，それによる空気の抵扰の影響も異なるためである が，いまここでは 1 つの例題として，放水試験における ゼットの昖散と余水栍における抬散とが全く同様に生 じ，したがって空気抵抗の影響も同じょうに作用すると 仮定して式 (19) を搪張適用し, 本文における計算式を もとにした多少の考察を行ないたい。

資料 スキージャンプ式余水路 (図一8 参照)

シュートの落差 $H=80 \mathrm{~m}$, 勾配 $=40^{\circ}$, 長さ $=103 \mathrm{~m}$, 越流堤上の水深 $h=6 \mathrm{~m}$, 水門幅 $=8 \mathrm{~m}$

1) $v_{0}$ および $h_{0}$

まず㘿流公式により $v$ 抢よび $q$ を計算し, ベルヌー 个式

$$
H+h+\frac{v^{2}}{2 g}=h_{0}+\frac{v_{0}^{2}}{2 g}+\int f_{r} \cdot \frac{d l}{R} \cdot \frac{v_{x}{ }^{2}}{2 g}
$$

に適用して， $h_{0}, v_{0}$ を概算する。ただし $v_{x}$ は $v$ と $v_{0}$ の平均値を用いた。

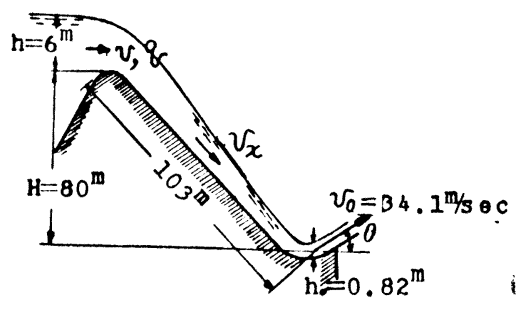

図一ス スキージャンプ式余水路 


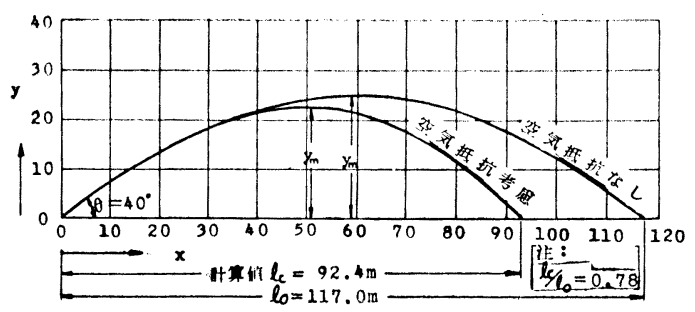

図一9大型射出の径路の比較図

スキージャンプ式余水路

$H=80 \mathrm{~m}, h=6 \mathrm{~m}, v_{0}=34.1 \mathrm{~m} / \mathrm{sec}, k=0.0195$

これより $h_{0}=0.82 \mathrm{~m}, v_{0}=34.1 \mathrm{~m} / \mathrm{sec}$ をえた。

2) 空気の抵抗を考慮した場合

先の例題と同じ方法で計算する。

$$
\begin{aligned}
& u_{1}=34.1 \times 0.766=26.12 \mathrm{~m} / \mathrm{sec}, \\
& v_{1}=34.1 \times 0.643=21.93 \mathrm{~m} / \mathrm{sec}
\end{aligned}
$$

射出水始点の断面は水門幅と同じに $8 \mathrm{~m}$ とすれば $m=\frac{8 \times 0.82}{8 \times 2+0.82 \times 2}=0.371 \mathrm{~m}$,

$k=0.00057 \times 3.34 .1+\frac{0.000021}{0.371^{1.35}}=0.0195$

$n=\tan ^{-1}(0.0195 \times 21.93)=0.404 \mathrm{rad}=239^{\circ}$,

$\sec \alpha=1.08757$,

より

$$
\begin{aligned}
& l=\frac{2.30}{9.8 \times 0.0195^{2}}-\log (1+2 \times 0.0195 \times 0.404 \\
& \quad \times 26.12)=92.4 \mathrm{~m} \\
& x_{m}=50.2 \mathrm{~m}, y_{m}=22.51 \mathrm{~m}
\end{aligned}
$$

次比 $y$ は式 (7) 上り

\begin{tabular}{|c|c|c|c|c|c|c|c|}
\hline \multicolumn{4}{|c|}{ 空気の抵抗を考虑した場合 } & \multicolumn{4}{|c|}{ 空気の抵扰を考虑しない場合 } \\
\hline$x(\mathrm{~m})$ & $y(\mathrm{~m})$ & 位 & 置 & $x(\mathrm{~m})$ & $y(\mathrm{~m})$ & 位 & 㯰 \\
\hline 0 & 0 & 始 & 点 & 0 & 0 & 始 & 点 \\
\hline 10 & 7.67 & & & 10 & 7.67 & & \\
\hline 20 & 13.91 & & & 20 & 13.91 & & \\
\hline 30 & 18.72 & & & 30 & 18.72 & & \\
\hline 40 & 21.45 & & & 40 & 22.09 & & \\
\hline 50 & 22.50 & & & 50 & 24.03 & & \\
\hline 50.5 & 22.51 & 最 & 点 & 58.5 & 24.54 & 最高 & 点 \\
\hline 55 & 22.27 & & & 60 & 24.49 & & \\
\hline 60 & 21.45 & & & 70 & 23.59 & & \\
\hline 65 & 20.06 & & & 80 & 21.23 & & \\
\hline 70 & 17.43 & & & 90 & 18.33 & & \\
\hline 75 & 15.36 & & & 100 & 12.20 & & \\
\hline 80 & 10.25 & & & 110 & 5.53 & & \\
\hline 85 & 7.78 & & & 115 & 1.67 & & \\
\hline 90 & 2.73 & & & 117 & 0 & 終 & 点 \\
\hline 92.4 & 0 & 終 & 点 & & & & \\
\hline
\end{tabular}

$y=\frac{2.30}{g k^{2}} \log \left(\cos g k^{3} \beta+\tan \alpha \cdot \sin g k \beta\right)$

$\frac{2.30}{g k^{2}}=617.2, \tan \alpha=\tan 23^{\circ} 9^{\prime}=0.42757$,

$\beta=\frac{e^{0.003726 x}-1}{0.09733}$

\section{表一6 大型射出水径路の計算例}

にxの值を人れて $y$ 在計算し，表一6 ならびに図一9に ホした。

3）空気の抵抗を考虑しない場合

この計算も先の例題と同じ方法で行ない, 表一6 なら びに 図一9に示した。

この場合の算式は

$$
y=x(0.839-0.00717 x)
$$

を用いた。

この計算例の場合 $l_{c} / l_{0}=0.78$ とかなり 空気抵抗の影 響が現われる。しかしさきの放水ゼットの例と同様初速 度が小さくなる, 規模の小さい射出水では $l_{c} / l_{0}$ は 1 に 近づくものと考えてよい。

\section{5.むすび}

本文において考究した，空気の抵抗を考慮したゼット の運動の径路の計算式作成の手法は多少の実測データが あれば，各種のゼットならびに固体の運動の場合の実用 胡算式の作成に適用できる。

本文ではフリーマンの消火用ノッズルの放水試験の結 果在使用して計算式索作成し，その例題を図一5 亿示 した。この放水試験の場合には, 空気抵抗の影響はゼッ トの始点から最淌点 $y_{m}$ に達する少し手前までごくお お゙かであるが， $y_{m}$ でやや目立ち，この点を過ぎると径 路は急に降下し始め抵抗の影響が大きくなることが示さ れている。

また空気の抵抗を考慮した到達距離 $l_{c}$ と考慮しない $l_{0}$ の比率は, 図一5 では $52 \%$, 図一6 では $90 \%$ とな り初速度 $v_{0}$ に影響されている。

初速度 $v_{0}$ の $l_{c} / l_{0}$ に対する影響は 図一7 に示したご とく, 初速度 $v_{0}$ が大きいと空気抵抗の影響は大きい が, 初速度 $v_{0}$ が小さくなると空気抵抗の影響も小さく なり，放水軌道は放物線に一致してくる。消防用ゼット の場合, $v_{0}=8.4 \mathrm{~m} / \mathrm{sec}$ 以下で軌道は放物線に一致する。 このような傾向は土木における余水吐の跳水でも存在 しうると考えられ，比較的規模の小さい射出水では現在 のまま空気抵抗の影響を無視しても差し支えないが，ス キージャンプのごとき大型射出水では空気抵抗の影響が 多少とも入ってくるのではないかと推察される。現在確 実なデータはないが，今後の問題点として指摘しておき たい。

\section{参 考文 献}

1）坂本竜雄：アーチダム越流の自由落下ナップの 分散につ いて, 電力中央研究所報告 No. $65068,1965$.

2）土木学会：水理公式集 昭和 38 年度版 p. $232,1963$.

3) Freeman : Treatise on Hydraulics, 10th Edition John. Wiley \& Sons Inc., p. 199, 1916. p. 196 197. 4) 同上

(1971.2.15 - 受付) 